\title{
CLONAL VARIATION FOR PHENOTYPIC PLASTICITY IN THE CORAL MADRACIS MIRABILIS
}

\author{
John F. Bruno ${ }^{1}$ And Peter J. Edmunds \\ Department of Biology, California State University, 18111 Nordhoff Street, Northridge, California 91330 USA
}

\begin{abstract}
Morphological plasticity is common among clonal organisms, including scleractinian corals, yet the role of phenotypic plasticity in coral ecology and evolution is largely unexplored. Additionally, it is unclear how much variation in plastic responses exists among individuals, populations, and species, and thus how much potential there is for natural selection to act on coral reaction norms. In the branching coral Madracis mirabilis, corallite architecture and density, branch diameter and spacing, and overall aggregate morphology all vary among environments. To examine the role of phenotypic plasticity in generating these patterns, clonal replicates of five genotypes of M. mirabilis were transplanted from each of two source populations into four treatment environments on the north coast of Jamaica. Flow rate, sedimentation, irradiance, water temperature, and salinity all varied among these environments. DNA fingerprinting was used to ensure that the 10 transplanted genotypes were genetically distinct. Six morphological traits (intersepta area, septa length, columella area, corallite area, corallite spacing, and branch tip diameter) were measured after transplantation to determine whether they were altered in response to environmental conditions. Because these traits were correlated, principal components analysis was used to define new, uncorrelated traits for analysis. Four of the five corallite traits and branch diameter were significantly affected by the environment, demonstrating that morphological variation among environments in M. mirabilis is due in large part to phenotypic plasticity. No difference was detected between the two source populations in the magnitude or direction of their plastic responses, but there was substantial variation among genotypes (genotype $\times$ environment interaction). Many of the phenotypic changes of both populations resulted in the transplants becoming morphologically similar to resident conspecifics in each treatment environment. Genotypes from both populations were able to maintain similar growth rates under diverse environmental conditions. Such morphological convergence by phenotypic plasticity may expand the ecological range of this species by enabling genotypes to tolerate spatially and temporally variable environments.
\end{abstract}

Key words: genotype $\times$ environment interaction; Madracis mirabilis; phenotypic plasticity; reaction norm; Scleractinia; skeletal structure.

\section{INTRODUCTION}

Scleractinian corals typically display a striking degree of morphological variation in colony shape and corallite structure along environmental gradients (Foster 1980, Brown et al. 1985), and among geographic regions (Veron 1981, Veron and Wallace 1984). Such variation can be caused by genetic differences among individuals and populations (Ayre and Willis 1988), by the environment (Foster 1979), or by both. Environmental control of morphological traits is termed phenotypic plasticity and a reaction norm describes the relationship between the phenotype and the environment (Bradshaw 1965, Schlichting 1986, Stearns 1989). Phenotypic plasticity is well known among numerous other taxa, including plants (Scheiner and

Manuscript received 22 January 1996; revised 1 December 1996; accepted 1 December 1996; final version received 13 January 1997.

${ }^{1}$ Present address: Department of Ecology and Evolutionary Biology, Box G-W, Brown University, Providence, Rhode Island 02912 USA.
Goodnight 1984, Schmitt 1993), sponges (Palumbi 1984), bacteria (Forst and Inouye 1988), fish (Meyer 1987), barnacles (Lively 1986), mollusks (MartínMora et al. 1995, Trussell 1996), and bryozoans (Harvell 1986), where it is thought to be ecologically important because it confers broad adaptability (Bradshaw 1965). Plasticity can also have important evolutionary implications (Sultan 1987). For example, within a single environment, plasticity can maintain genetic diversity under stabilizing selection by enabling a variety of genotypes to display a similar advantageous phenotype (Bradshaw 1965, Sultan and Bazzaz 1993). In addition, there are a number of mechanisms through which phenotypic plasticity might accelerate the appearance of novel phenotypes and the rates of speciation and macroevolution (West-Eberhard 1989).

A variety of life history traits indicate that plasticity could be important in corals as well. For example, corals are sessile and many are clonal (Hughes 1983, 1989), relying heavily on asexual modes of reproduction, including fragmentation (Tunnicliffe 1981, High- 
smith 1982), fission (Hughes and Jackson 1985), and the production of parthenogenic larvae (Stoddart 1983). Due in part to indeterminate growth (Hughes and Connell 1987, Sebens 1987), and the absence of physiological senescence (Hughes 1983, but see Meesters and Bak 1995), individual colonies can live for centuries and their clonal replicates for even longer (Hughes 1983, Potts 1984, Potts et al. 1985). Furthermore, many important reef-building corals are rarely seen as recruits (Bak and Engel 1979), suggesting that sexual recruitment is episodic as it is in other clonal cnidarians (Ayre 1984) and in clonal, aquatic animals in general (Jackson and Coates 1986). Together, these attributes can act to restrict genotypic diversity within coral populations and favor spatial dominance by a few successful genotypes (Potts et al. 1985, Hunter 1993). Under such conditions phenotypic plasticity would be predicted to be particularly valuable in alleviating some of the effects of reduced genetic diversity (Bradshaw 1965).

Phenotypic plasticity has been documented in a number of coral species for traits, including whole-colony morphology (Vaughan 1911, 1917, Maragos 1972, Willis 1985), tissue pigmentation (Gleason 1992), and corallite structure (Foster 1979), as well as physiological (Lesser et al. 1994) and behavioral traits (Chornesky 1983). However, few data are available on crucial aspects of coral plasticity, such as how much variation in plastic responses exists among individuals, populations, and species, and how specific plastic traits change in response to particular environmental characters. This is in contrast to the large body of literature documenting variation in plastic responses at a number of levels in plants, as well as its prominence in general theories of phenotype evolution (Via and Lande 1985, Schlichting 1986, Schlichting and Pigliucci 1995). As a result it is unclear when and where (if ever) coral plasticity is beneficial, how much potential there is for natural selection to act on the plastic responses of corals, and what role (if any) plasticity plays in coral evolution and speciation.

The purpose of this study was to obtain a detailed understanding of plasticity in the branching coral Madracis mirabilis. A reciprocal transplant experiment was performed in which clonal replicates of several genotypes were exposed to different environmental treatments. This design allowed a comparison of the magnitude and direction of plasticity between populations and among genotypes. Six physiologically important morphological traits were measured after transplantation to determine whether they were altered in response to the environmental treatments. Specifically, the following questions were addressed: (1) To what degree do genetic and environmental factors affect the morphology of M. mirabilis? (2) Are there between-population and/or among-genotype differences in the magnitude or direction of plasticity in M. mirabilis?

\section{Materials And Methods \\ Experimental organism}

Madracis mirabilis was chosen for this study because it displays a large amount of morphological variation among environments, and because its branching morphology allowed numerous clonal replicates to be collected from each genotype. Additionally, field observations suggested that skeletal morphology in $M$. mirabilis might be determined in part by the environment. For example, large, continuous aggregations of $M$. $\mathrm{mi}_{\text {- }}$ rabilis living in backreef/lagoon environments in Jamaica, spanning numerous microenvironments along a depth range of $>10 \mathrm{~m}$, display the entire range of morphologies that have been observed within this species (J. F. Bruno, unpublished data). Because M. mirabilis can reproduce asexually through fragmentation (Bak and Criens 1981, Highsmith 1982), both spatial (fragments can be transported into novel environments) and temporal (local conditions can change after an aggregation becomes established) heterogeneity could expose a genotype to novel environments during its lifespan.

Madracis mirabilis is found in a variety of habitats from 5 to $50 \mathrm{~m}$ in depth throughout the Caribbean (Schindler 1985, Lewis and Snelgrove 1990, Fenner 1993). In forereef environments, it forms hemispherical aggregations of branches up to $2 \mathrm{~m}$ in diameter (Fig. $1 \mathrm{~A}$ ), and in backreef and lagoon environments it can form larger aggregations of $>5 \mathrm{~m}$ in diameter. Separate branches within an aggregation of $M$. mirabilis are physically connected by a common skeleton but not by tissue. As a branch extends, the tissue at the base of the branch recedes and the newly exposed portion of the skeleton can become colonized by boring sponges and algae. Thus, each branch is a functional colony of physiologically integrated polyps (Connell 1973), and each aggregation is likely to be a genotype made up of numerous clonal replicates (branches).

\section{Environment}

All field work took place on the north coast of Jamaica at the Discovery Bay Marine Laboratory (DBML). The reefs near DBML were originally described by Goreau (1959) and subsequently in numerous other studies (e.g., Goreau and Goreau 1973, Liddell and Ohlhorst 1987, 1992, Edmunds and Bruno 1996). Four reef sites were used as treatment environments. Two were located on the exposed forereef at Dairy Bull cove, at $10 \mathrm{~m}$ (DB10) and $20 \mathrm{~m}$ depth (DB20). The other two were $<3 \mathrm{~km}$ west of Dairy Bull at Columbus Park (10 m depth), which is a protected lagoon environment within Discovery Bay. Columbus Park Springs (CPSP, $10 \mathrm{~m}$ depth) was adjacent to underwater, freshwater springs, which are numerous at this site (D'Elia et al. 1981). The other lagoon environment (CP10) was $25 \mathrm{~m}$ from the nearest spring, but also at $10 \mathrm{~m}$ depth. Differences in the physical con- 

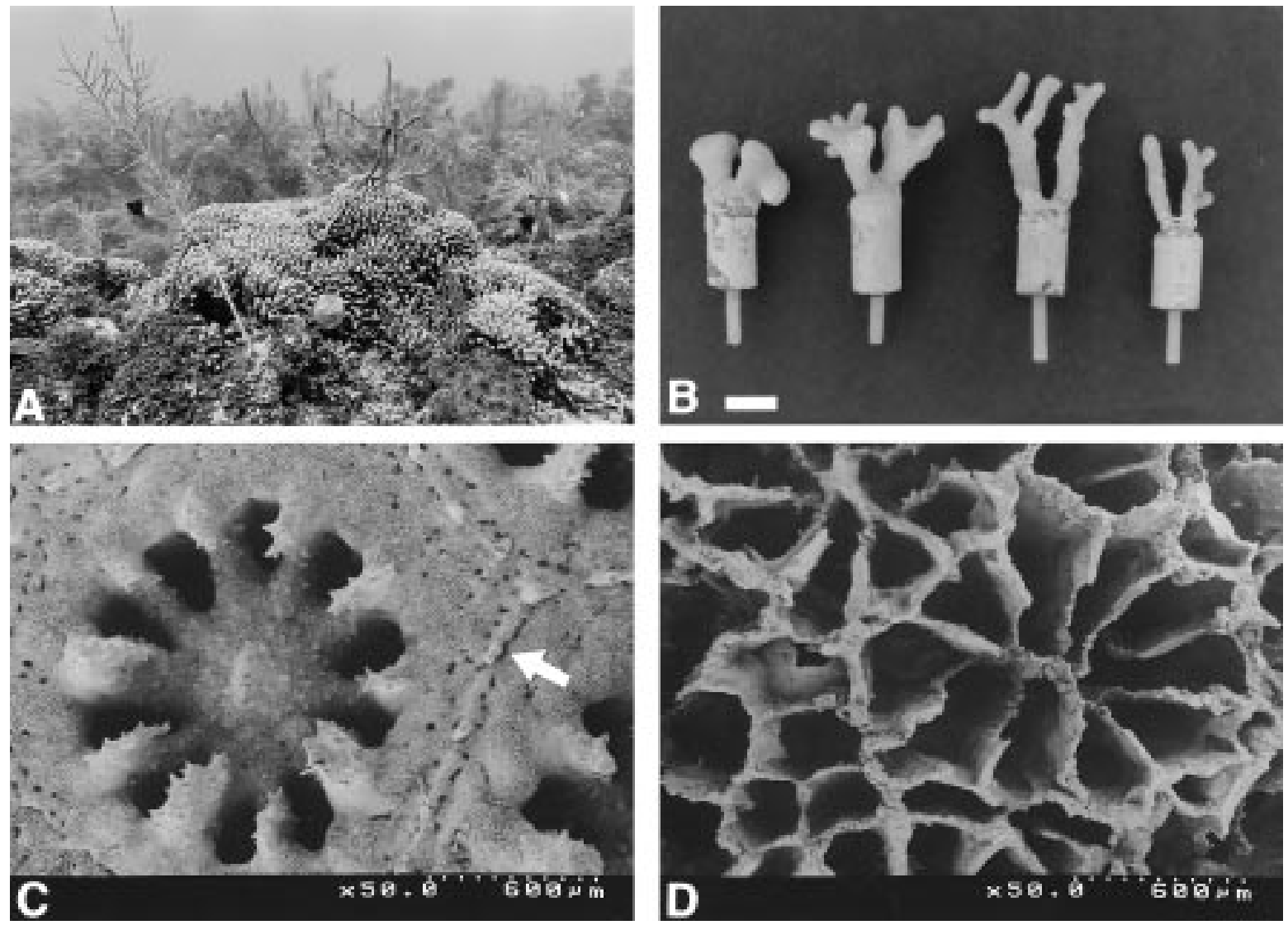

FIG. 1. (A) Madracis mirabilis aggregation from Conch Reef, Florida Keys (25 m depth); (B) branches of M. mirabilis after transplantation from Dairy Bull at $20 \mathrm{~m}$ to (from left): Columbus Park Springs, Columbus Park at $10 \mathrm{~m}$, Dairy Bull at $10 \mathrm{~m}$, Dairy Bull at $20 \mathrm{~m}$ (scale bar $=1 \mathrm{~cm}$ ); (C) scanning electron micrograph of corallites of M. mirabilis from Dairy Bull at $10 \mathrm{~m}$; (D) scanning electron micrograph of corallites of M. mirabilis from Columbus Park Springs at $10 \mathrm{~m}$. Note the arrow in $\mathrm{C}$ pointing to the hexagonally shaped ridges (pseudocostae) surrounding the corallite from Dairy Bull at $10 \mathrm{~m}$, which are absent in the Columbus Park Springs at $10 \mathrm{~m}$ corallite.

ditions among the four treatment environments have been described in previous papers and include temperature, salinity, irradiance (Foster 1979, Edmunds 1989, Bruno 1995), nutrient concentration (D'Elia et al. 1981), and flow rate (Helmuth and Sebens 1993). These physical characters are summarized in Table 1. In this paper, the corals naturally living in each of the treatment environments are referred to as residents (as opposed to those that were experimentally transplanted there) and all of the conspecific corals from each environment are loosely termed a population. However, it is likely that our populations are all part of a larger metapopulation, and that they are genetically homogeneous due to gene flow between each other and external sources.

\section{Natural morphological variation}

A number of morphological traits in Madracis mirabilis vary along environmental gradients (Schindler 1985, Fenner 1993, Bruno 1995, Sebens et al. 1997). For example, branches from forereef habitats (e.g., DB10 and DB20) are generally cylindrical, while in lagoon habitats (e.g., CP10 and CPSP) branches have a larger diameter and bulbous, flattened tips (Fig. 1B; Schindler 1985, Fenner 1993, Bruno 1995). Interconnecting, hexagonally shaped ridges (pseudocostae) often surround the corallites of forereef branches but are absent in the lagoon (Fenner 1993; Fig. 1C, D). Additionally, the spacing among corallites is larger in forereef habitats than in lagoon environments (Schindler 1985, Bruno 1995; Fig. 1C, D). Corallites on lagoon branches and on the terminal ends of forereef branches have 10 thin primary septa and the columella is formed from junction of the septa (Fig. 1C, D). Corallites on the sides of branches from the forereef have a prominent columella, 10 thicker primary septa, and much smaller intersepta areas than lagoon corallites. Aggregate-level traits including branch spacing and aggregate shape also vary among environments (Bruno 1995, Sebens et al. 1997).

Four corallite traits (intersepta area, ISA; columella area, CLA; corallite area, CA; and corallite spacing, CS; Fig 2), and two branch traits (branch tip diameter, $\mathrm{BD}$; and branch spacing, BSP) were measured on Mad- 
TABLE 1. Relative differences in environmental characteristics of the four treatment environments. Values in parentheses were measured during June 1994 (Bruno 1995). Site abbreviations: DB10, Dairy Bull at $10 \mathrm{~m}$; DB20, Dairy Bull at 20 $\mathrm{m}$; CP10, Columbus Park at $10 \mathrm{~m}$; CPSP, Columbus Park Springs at $10 \mathrm{~m}$.

\begin{tabular}{|c|c|c|c|c|c|}
\hline Characteristic & Source & DB10 & DB20 & CP10 & CPSP \\
\hline Water velocity & $\begin{array}{l}\text { Helmuth and Sebens 1993; J. } \\
\text { F. Bruno, unpublished data }\end{array}$ & high & med & low & high \\
\hline Wave energy & $\begin{array}{l}\text { Brakel 1976; J. F. Bruno, un- } \\
\quad \text { published data }\end{array}$ & high & med & low & low \\
\hline Sedimentation rate & $\begin{array}{l}\text { Foster 1980, Edmunds } 1989, \\
\quad \text { Bruno } 1995\end{array}$ & low & low & med & high \\
\hline $\begin{array}{l}\text { Light intensity (\% surface ir- } \\
\text { radiance) }\end{array}$ & Edmunds 1989, Bruno 1995 & high $(26 \%)$ & med $(20 \%)$ & med $(18 \%)$ & med $(18 \%)$ \\
\hline Temperature $\left({ }^{\circ} \mathrm{C}\right)$ & Edmunds 1989, Bruno 1995 & high (29.5) & high (29.5) & med (28.5) & low (27.1) \\
\hline Nutrient level (nitrogen) & D'Elia et al. 1981 & low & low & med & high \\
\hline Salinity (g/kg) & Bruno 1995 & high (35.0) & high (35.0) & med (30.0) & low $(26.5)$ \\
\hline
\end{tabular}

racis mirabilis aggregates from the four treatment environments (residents). These measurements were used to quantify field observations of morphological variation among environments and for comparison with transplanted corals (refer to Fig. 2 for further description of measured traits). Corallite area was included in the analysis so that the other corallite traits could be normalized to corallite size. To quantify the corallite traits, three branches were collected from each of five genotypes selected at random (each separated by $>25$ m) from each treatment environment. Three haphazardly selected corallites, $2 \mathrm{~cm}$ from the terminal branch end, were analyzed on each branch. Two measurements were made from each corallite for ISA (the largest and

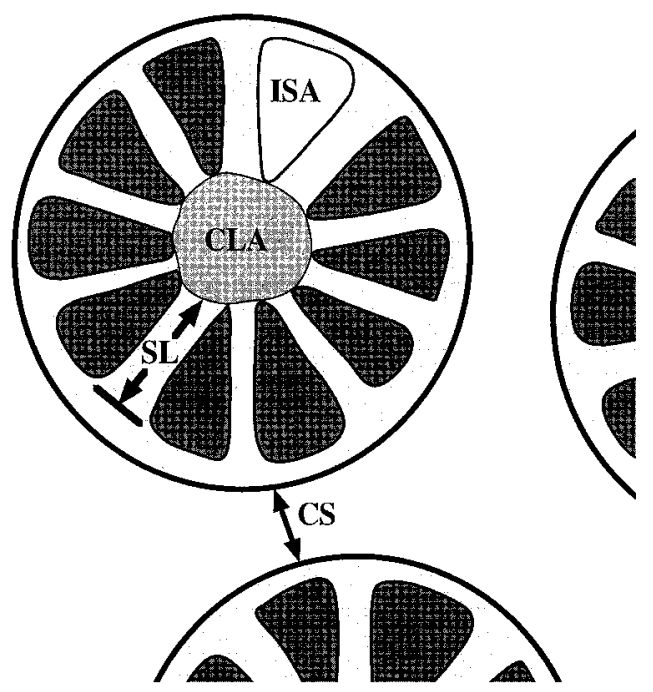

FIG. 2. Morphometric traits that were measured to quantify plasticity in Madracis mirabilis. ISA, intersepta area; CLA, columella area; SL, septa length; CS, corallite spacing Traits not shown in figure include: $\mathrm{CA}$, corallite area; $\mathrm{BD}$, branch tip diameter; BSP, branch spacing; and $\mathrm{CD}$, corallite diameter. The corallite is the structure in the coral skeleton that houses a single coral polyp. Each septa acts as a wall to divide the corallite into separate chambers (intersepta area). The columella is the central region of the corallite and is located at the junction of the 10 septa in the case of $M$. mirabilis. opposing area between adjacent septa), and CS (distance to the two nearest corallites), and a single measurement was made on each corallite for CLA and CA. To prepare the corals for analysis, the skeletons were bleached (with $50 \%$ bleach) to remove the tissue, rinsed in distilled water, and dried. Planar images of the skeleton surface $(100 \times)$ were made of the branches with a video camera fitted to a dissecting microscope, and these were analyzed with imaging software (NIH Image 1.43). The two branch traits (BD and BSP) were measured in situ on five $M$. mirabilis aggregates (the same aggregates from which branches had been collected) from each of the four treatment environments. Branch diameter was measured with calipers $1 \mathrm{~cm}$ from the end of 10 branches on each aggregate. Branch spacing was measured as the distance between adjacent branches (10 pairs/aggregate).

Because the six measured skeletal traits were correlated, a one-factor MANOVA (MGHL platform, SYSTAT 3.0) was used to analyze multivariate variation among environments. After establishing the significance of the environment effect with MANOVA, univariate comparisons were performed with ANOVA. Genotype mean values for each trait were the statistical replicates, and analysis was performed on log-transformed data after all statistical assumptions had been met (Zar 1996). Environment was considered a fixed effect in all analyses because the four environments were chosen based on: (1) a priori assessment of sitespecific variation in the morphology of Madracis mirabilis, and (2) data describing differences in environmental factors known to affect coral morphology (Table $1)$.

Principal components analysis (PCA) was carried out on the correlation matrix of log-transformed genotype means to investigate multivariate associations among the traits and to examine the nature of the multivariate differences among groups. Principal components (PC) that explained $>10 \%$ of the total variance or that had an eigenvalue of $>1.0$ were interpreted (Nichols 1977, Jolliffe 1986). However, the final decision as to which components to use in subsequent analyses was based 
TABLE 2. Morphometric comparisons (means $\pm 1 \mathrm{SE}$ ) of Madracis mirabilis aggregations naturally living (resident corals) in each of the four treatment environments. $F$ values are from univariate comparisons (ANOVA, one fixed factor $=$ site; $\mathrm{df}=3,16)$ of each trait among the four environments. Multivariate comparison (fixed-effect MANOVA) among sites was significant (Wilks' $\lambda=0.012 ; F=6.70 ; \mathrm{df}=18,31 ; P<0.001$ ). DB10, Dairy Bull at $10 \mathrm{~m}$; DB20, Dairy Bull at 20 $\mathrm{m}$; CP10, Columbus Park at $10 \mathrm{~m}$; CPSP, Columbus Park Springs at $10 \mathrm{~m}$.

\begin{tabular}{lcrrrr}
\hline \hline \multicolumn{1}{c}{ Character } & DB10 & \multicolumn{1}{c}{ DB20 } & CP10 & \multicolumn{1}{c}{ CPSP } & $F$ \\
\hline Corallite area $\left(\mathrm{mm}^{2}\right)$ & $1.75 \pm 0.25$ & $1.56 \pm 0.17$ & $1.58 \pm 0.09$ & $1.69 \pm 0.10$ & 0.29 \\
Columella area $\left(\mathrm{mm}^{2}\right)$ & $0.35 \pm 0.04$ & $0.30 \pm 0.05$ & $0.23 \pm 0.03$ & $0.20 \pm 0.03$ & $3.05 \dagger$ \\
Intersepta area $\left(\mathrm{mm}^{2}\right)$ & $0.04 \pm 0.01$ & $0.04 \pm 0.01$ & $0.07 \pm 0.01$ & $0.09 \pm 0.01$ & $11.98^{* * *}$ \\
Corallite spacing $(\mathrm{mm})$ & $0.44 \pm 0.03$ & $0.44 \pm 0.04$ & $0.38 \pm 0.10$ & $0.18 \pm 0.03$ & $6.28^{*}$ \\
Branch tip diameter $(\mathrm{mm})$ & $6.92 \pm 0.37$ & $5.71 \pm 0.28$ & $7.03 \pm 0.36$ & $12.68 \pm 1.27$ & $25.09^{* * *}$ \\
Branch spacing $(\mathrm{mm})$ & $7.90 \pm 0.20$ & $11.30 \pm 0.80$ & $9.60 \pm 0.40$ & $6.00 \pm 0.30$ & $16.92^{* * *}$ \\
\hline
\end{tabular}

$* P<0.05 ; * * * P<0.001 ; \dagger P<0.075$.

on an examination of associated eigenvectors (component loadings) to ascertain their utility in providing biologically meaningful information (Nichols 1977, Gauch 1982).

\section{Transplant experiment}

Twelve branches (3-6 cm in length) were collected from each of five genotypes selected at random from the DB20 (DB20 population; genotypes 1-5) and the CP10 (CP10 population; genotypes 6-10) environments. These 10 genotypes were distinct from those sampled to quantify resident morphology in each environment (i.e., previous section). All genotypes sampled within a population were separated by $>25 \mathrm{~m}$ to increase the probability that they were genetically distinct. Each branch was glued into a short piece of plastic pipe ( $1 \mathrm{~cm}$ in diameter) with marine epoxy (Z-Spar Splash Zone Compound A-788, Kop-Coat, Los Angeles, California; epoxy did not appear to adversely affect the corals, as many grew over the dried epoxy within $4 \mathrm{wk}$ ), and a nylon screw was set in the opposite end (Fig. 1B). The 12 branches from each genotype were randomly assigned to 12 different Plexiglas plates $(15 \times 25 \mathrm{~cm})$ and were randomly assigned positions within each plate. Eight additional corals, which were not used in the analysis for this study, were also attached to the same plates to form small, artificial aggregations. Branches were placed as close as possible (10-20 mm between adjacent branches) to mimic natural spacing (Table 2), but were not placed in direct contact to avoid aggressive interactions (Lang and Chornesky 1990). Three randomly selected plates were transplanted to each of the four treatment environments (DB10, DB20, CP10, and CPSP) for $96 \mathrm{~d}$, beginning in February 1994. Corals were kept in a flowing seawater table during the preparation of plates and were transplanted to their respective environments within 48 $\mathrm{h}$ of collection. The plates within each environment were separated by $>10 \mathrm{~m}$.

Morphological plasticity was quantified by measuring six skeletal traits at the conclusion of the transplant experiment: intersepta area, ISA; septa length, SL; columella area, CLA; corallite area, CA; corallite spacing, CS; and branch tip diameter, BD (Fig. 2). The mor- phological traits of the transplanted corals were quantified in the same manner as the resident corals ( 3 corallites/branch). Two measurements of SL were made from each corallite (the longest and opposing septa). Quantification of ISA, CLA, CA, CS, and BD is described above.

The results of the transplant experiment were analyzed in two separate sets of analyses. The purpose of the first was to examine the effects of the population (origin), genotype, and environment on coral morphology, and to compare plastic responses between populations and among genotypes. Because the six measured skeletal traits were correlated, PCA was performed on log-transformed measurements of the six traits from both populations (statistical replicates were mean branch values for each trait) and the resulting uncorrelated variables were used in ANOVA. PCA results also aided in an examination of multivariate plastic responses. Log-transformed scores from the first three PCs (see above for component selection criteria) were analyzed with three-way ANOVA (Scheffé mixed model sensu Fry 1992, fixed factor = environment, random factor $=$ population, nested factor = genotype) .

The second set of analyses was carried out to compare the morphologies of the corals transplanted into each environment with the resident corals naturally living in those environments. An additional PCA was performed on the genotype means (log transformed) of both the transplanted and the resident corals using the five traits that had been quantified on both groups: CA, CLA, ISA, CS, and BD. The log-transformed scores from the first three principal components were analyzed with two-way ANOVA (fixed-factor 1 = environment, fixed-factor 2 = population). In this analysis the population factor consisted of three levels, including the resident corals and the transplanted corals from each of the two source populations, and was considered a fixed factor because the resident level was specifically chosen to determine whether the transplants adopted the morphology of their resident conspecifics.

Reaction norms are a graphic portrayal of the mean response of individual genotypes to the environment, and allow a visual comparison of magnitudes and patterns of plasticity to be made among genotypes and 
populations (Stearns 1989). The environment can consist of two or more levels of a single manipulated factor as would be controlled in a laboratory experiment (continuous environments), or two or more natural environments known to differ in a number of factors (discrete environments), as is usually the case in a field transplant experiment (Via et al. 1995). In the present study, reaction norms were plotted for both the original measured traits and for the first three principal components. For the measured traits CLA, SL, and ISA, reaction norms were plotted as proportions of corallite size, as this is likely to be more biologically important than their absolute size (Patterson 1992). In all reaction norms, the four environmental treatments are plotted in an arbitrary order and do not represent a single environmental gradient (Table 1).

\section{Transplant growth and survival}

The growth (linear extension and skeletal accretion) and survival of the transplanted corals were measured as estimates of fitness. In colonial corals, growth is closely linked to fecundity because the reproductive capability of modular organisms increases with living surface area (Connell 1973, Hughes 1989). Furthermore, larger colony size decreases the risk of wholecolony mortality (Hughes and Jackson 1985, Hughes and Connell 1987). Therefore, growth rate is likely to be an important component determining overall colony fitness (Jackson 1979, Hughes and Jackson 1985).

Linear extension was determined by measuring the length of each branch, before and after transplantation. Skeletal accretion was quantified as an increase in dry skeletal mass using the buoyant weighing technique (Davies 1989). At the end of the transplant period, both measures of skeletal growth were normalized to surface area of living tissue as determined with the methylene blue dye method (described in Hoegh-Guldberg 1988). Colony survival was measured by scoring each coral as alive or dead at the completion of the transplant period.

\section{DNA fingerprinting}

Because Madracis mirabilis can reproduce asexually through fragmentation (Bak and Criens 1981, Highsmith 1982), DNA fingerprints of the genotypes used in the transplant experiment were prepared to ensure that all 10 genotypes were genetically distinct (Jeffreys et al. 1985a). Animal DNA was extracted by crushing a branch of each genotype in $2 \mathrm{~mL}$ of ice-cold guanadinium hydrochloride buffer $(8 \mathrm{~mol} / \mathrm{L}$ GHCL, 0.1 $\mathrm{mol} / \mathrm{L}$ sodium acetate, $5 \mathrm{mmol} / \mathrm{L}$ dithiothreitol, $0.5 \%$ $\mathrm{N}$-lauryl sarcosine) and storing the resulting slurry at $4^{\circ} \mathrm{C}$. The samples were cleaned with SS phenol/chloroform/isoamyl alcohol (25:24:1), followed by a chloroform/isoamyl alcohol (24:1) cleaning. DNA was then precipitated by adding $7.5 \mathrm{~mol} / \mathrm{L}$ ammonium acetate and ice-cold isopropanol and chilling to $-20^{\circ} \mathrm{C}$ overnight. DNA samples were dissolved in Tris/EDTA buff- er to $1 \mu \mathrm{g} / \mu \mathrm{L}$, treated with RNase, digested with Hae III, and separated on two agarose gels for $16 \mathrm{~h}$ at 30 V. The DNA was then transferred to nylon membranes by southern blotting.

Membranes were probed with the oligonucleotide $\mathrm{GTG}_{5}$, which was 3 '-end-labeled with DIG-ddUTP (Genius System, Boehringer, Mannheim, Germany). Membranes were hybridized for $6 \mathrm{~h}$ at $38^{\circ} \mathrm{C}$ and detected with chemiluminescence. The migration distance of resolvable bands between 1.6 and $10.0 \mathrm{~kb}$ (kilobase) was measured from autoradiograms. For quantitative analysis, bands were assigned to bins that were calculated from the error in estimating band size (after Gibbs et al. 1991) and the resulting banding patterns were used for comparisons among genotypes. Previous experiments have demonstrated that these methods can produce banding patterns from coral host DNA that are repeatable for a single colony and are not confounded by the DNA of the symbiont zooxanthellae (P. J. Edmunds, unpublished data).

\section{RESULTS}

\section{Natural morphological variation}

MANOVA revealed that the multivariate morphology of Madracis mirabilis resident corals varied significantly among the four treatment environments (based on Wilks' $\lambda$, which was $0.012 ; F=6.70$; df $=$ $18,31 ; P<0.001)$. Additionally, ANOVAs found that four of the six univariate traits varied significantly (ISA, CS, BD, and BSP), one varied marginally (CLA, $P<0.075)$, and one was not significant (CA, Table 2). For PCA on resident coral genotype means, the first principal component (PC1) explained $53 \%$ of the multivariate variance and was characterized by high positive loadings (eigenvectors) for CS and CLA, and high negative loadings BD and ISA (Table 3). PC2 explained $24 \%$ of the variance and was characterized mainly by positively weighted CA, while PC3 explained $24 \%$ of the variance and was defined by BSP.

\section{Transplant experiment}

After transplantation to CPSP the proportion of the corallite occupied by the columella decreased, while the SL and ISA (proportional to corallite size) increased (Fig. 3). This resulted in the CPSP corallites adopting a much more porous or open corallite morphology similar to that of the resident corals (Fig. 1D). CS decreased in the lagoon environments (CP10 and CPSP), while BD increased in CPSP (Fig. 3). In the PCA of transplanted corals, $\mathrm{PC} 1$ explained $50 \%$ of the variance and was defined by high positive loadings for ISA and SL, and negative loadings for CS and CLA (Table 3). PC2 explained $22 \%$ of the variance and was characterized mainly by positively weighted CA and CLA, and PC3 was defined mainly by BD, which was weighted negatively (refer to Table 3 for eigenvalues and eigenvectors). ANOVA of the first three principal com- 
TABLE 3. Principal components analysis of: five skeletal traits measured on Madracis mirabilis collected from the four treatment environments (residents), six traits measured after transplantation to the treatment environments (transplants), and five traits of both transplants and the resident corals in each environment (residents and transplants).

\begin{tabular}{|c|c|c|c|c|c|c|c|c|c|}
\hline \multirow[b]{2}{*}{ Parameter } & \multicolumn{3}{|c|}{ Residents } & \multicolumn{3}{|c|}{ Transplants } & \multicolumn{3}{|c|}{ Residents and transplants } \\
\hline & $\mathrm{PC} 1$ & $\mathrm{PC} 2$ & PC3 & PC1 & $\mathrm{PC} 2$ & PC3 & PC1 & $\mathrm{PC} 2$ & $\mathrm{PC} 3$ \\
\hline Eigenvalue & 3.18 & 1.46 & 0.87 & 2.99 & 1.30 & 0.89 & 2.37 & 1.24 & 0.73 \\
\hline Explained variance $(\%)$ & 52.99 & 24.37 & 14.51 & 49.85 & 21.73 & 14.81 & 47.36 & 24.78 & 14.61 \\
\hline \multicolumn{10}{|l|}{ Component loadings } \\
\hline $\mathrm{CA}$ & -0.04 & 0.98 & 0.04 & 0.65 & 0.70 & 0.09 & 0.49 & 0.82 & -0.22 \\
\hline $\mathrm{CS}$ & 0.92 & -0.05 & -0.27 & -0.73 & 0.41 & -0.03 & -0.76 & 0.20 & 0.24 \\
\hline BD & -0.85 & 0.13 & -0.32 & 0.44 & -0.21 & -0.86 & 0.69 & -0.17 & 0.70 \\
\hline CLA & 0.71 & 0.59 & -0.37 & -0.47 & 0.74 & -0.35 & -0.55 & 0.66 & 0.38 \\
\hline ISA & -0.84 & 0.36 & 0.25 & 0.90 & 0.16 & 0.05 & 0.88 & 0.26 & 0.02 \\
\hline SL & $\ldots$ & $\ldots$ & $\ldots$ & 0.91 & 0.15 & 0.11 & $\ldots$ & $\ldots$ & $\ldots$ \\
\hline BSP & 0.64 & 0.15 & 0.70 & $\cdots$ & $\cdots$ & $\cdots$ & $\cdots$ & $\cdots$ & $\ldots$ \\
\hline
\end{tabular}

Notes: All PCA was performed on log-transformed data. Refer to Fig. 2 for trait abbreviations. Ellipses denote traits not included in the analysis.

ponents found a significant environmental effect for PC1 and PC3 but not for PC2 (Table 4), which was strongly weighted by CA. No significant effect was detected for the source population or the environment $X$ population interaction, which is illustrated by the similarity of reaction norms of the DB10 and CP10 populations (Figs. 3 and 4). The main genotype effect, however, was highly significant for all three components, and there were significant genotype $\times$ environment interactions $(\mathrm{G} \times \mathrm{E})$ for the first two components, and marginally significant $\mathrm{G} \times \mathrm{E}$ for PC3 (Table 4). These effects are demonstrated, respectively, by differences in elevation of reaction norms and by crossing or discordant reaction norms (e.g., PC2). In the statistical design used in this analysis, comparisons are made among all 10 genotypes. However, further analysis (a separate ANOVA for each population) found the same patterns of significant genotype and $G \times E$ effects among the five genotypes within each population ( $\mathrm{J}$. Bruno, unpublished data).

The PCA that included genotype trait means of both transplanted and resident corals produced three PCs that had component loadings that were very similar to those from the other two PCAs (Table 3). The mean scores of transplants and residents were broadly similar for PC1 and PC2, but not for PC3 in the CPSP environment (Fig. 5). In the two-way ANOVAs used to analyze these PCs, a significant environment $\times$ population interaction indicated that the morphology of the three populations differed significantly within environments. This interaction term was not significant for PC1 and $\mathrm{PC} 2$, but was highly significant for PC3, which was heavily weighted by BD (Table 5). The main environment factor had a highly significant effect on PC1 but not on PC2 (the significance of the two main effects was not tested in PC3 due to the significant interaction term; Zar 1996).

\section{Transplant growth and survival}

Most of the transplanted corals doubled their dry skeletal mass and length during the 96-d transplant period. Neither measure of growth varied significantly among environments, populations, or genotypes (Fig. 6, Table 6). However, there was a nonsignificant trend for corals from the DB10 population to extend faster than those from the CP10 population. There was no among-genotype variation for linear extension and skeletal accretion, suggesting that no one genotype grew faster in all environments than any other genotype. There was also no significant $\mathrm{G} \times \mathrm{E}$ for linear extension and skeletal accretion (Table 6), indicating that rankings of genotype by growth rates did not vary across environments. Although the corals in the CP10 environment grew as fast as the corals transplanted to the other three environments, they experienced more frequent partial overgrowth by sponges, bryozoans, and bivalves. The corals transplanted to the forereef that experienced partial overgrowth were overgrown by brown algae, especially Dictyota spp. Only 4 branches (out of 120 branches) experienced whole-colony mortality during the transplant period ( 2 branches from each population), all of which had been transplanted to CP10. Survivorship frequencies were not independent of the environmental treatments (chi-square analysis: $\chi^{2}=12.42$; df $\left.=3 ; P<0.01\right)$.

\section{DNA fingerprinting}

Scorable banding patterns were successfully produced from 8 of the 10 transplanted genotypes (four patterns from each source population). In the fingerprints from the other two genotypes, the bands were not well defined and could not be confidently scored. The eight scorable patterns consisted of 4-15 bands ranging in size from 1.6 to $10.0 \mathrm{~kb}$. Assigning all scorable bands to 12 bins produced $7.1 \pm 0.9$ bands/colony (mean $\pm 1 \mathrm{sE}$, Table 7). Banding patterns of a single colony were reproducible when duplicate samples were run on separate gels (J. Bruno, unpublished data). None of the eight genotypes that were successfully fingerprinted had matching banding patterns (Table 7). This result, in addition to the fact that each of the 5 geno- 
A) DB10 Genotypes
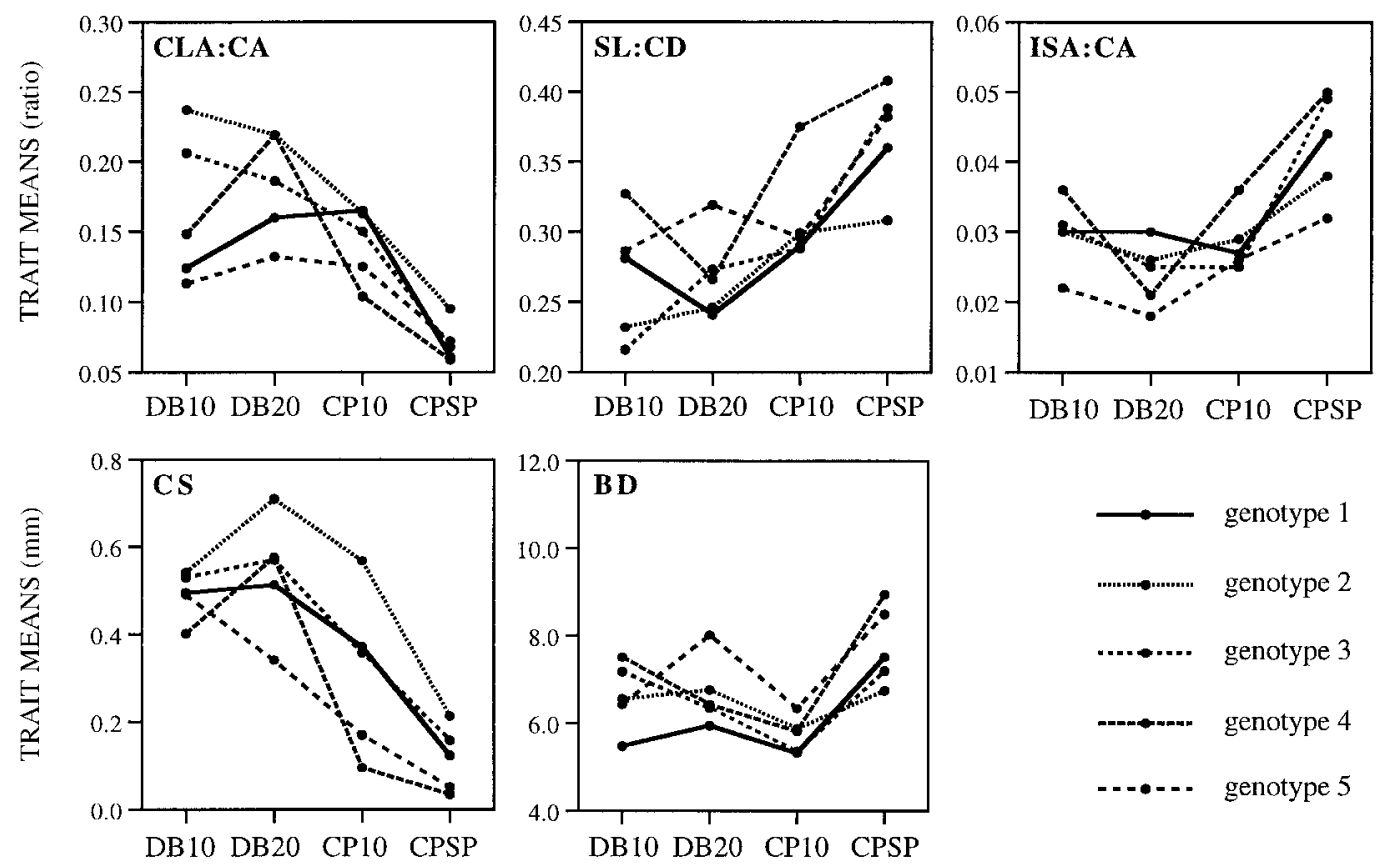

B) CP10 Genotypes
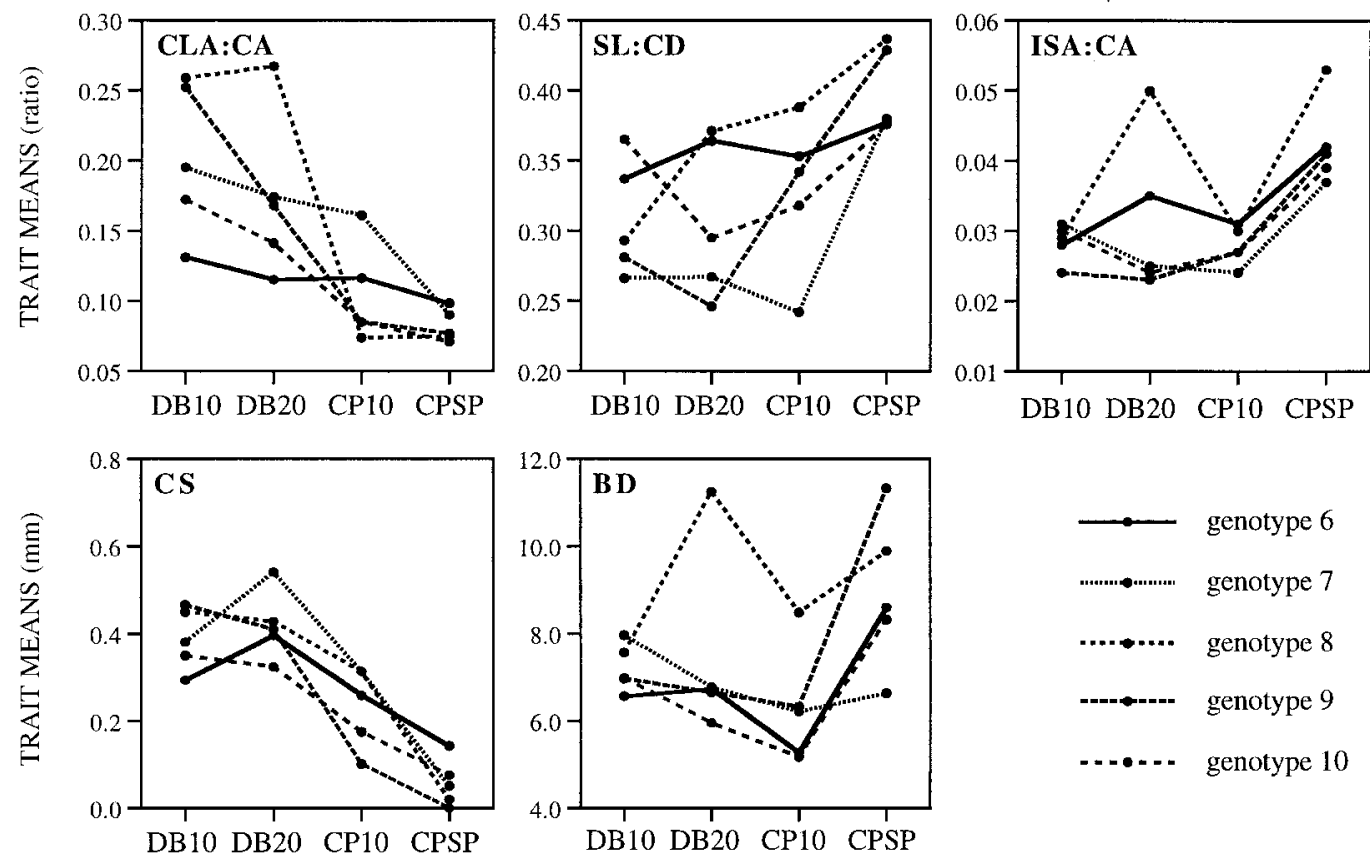

ENVIRONMENT

FIG. 3. Reaction norms of five traits in response to the environmental treatments. (A) Dairy Bull (DB10) genotypes; (B) Columbus Park (CP10) genotypes. Values are untransformed means. Refer to Table 1 for a summary of environmental characteristics of each treatment environment and to Fig. 2 for trait abbreviations. DB10, Dairy Bull at 10 m; DB20, Dairy Bull at $20 \mathrm{~m}$; CP10, Columbus Park at $10 \mathrm{~m}$; CPSP, Columbus Park Springs at $10 \mathrm{~m}$. 
TABLE 4. Results of three-factor nested ANOVA testing the effects of the treatment environment, origin population, and genotype on the first three principal components (PC1-3).

\begin{tabular}{|c|c|c|c|c|c|c|c|}
\hline \multirow[b]{2}{*}{ Source } & \multirow[b]{2}{*}{$\mathrm{df}$} & \multicolumn{2}{|c|}{ PC1 } & \multicolumn{2}{|c|}{ PC2 } & \multicolumn{2}{|c|}{ PC3 } \\
\hline & & MS & $F$ & MS & $F$ & MS & $F$ \\
\hline Environment (E)末 & 3 & 17.251 & $13.996 *$ & 3.977 & 2.254 & 6.488 & $13.491 *$ \\
\hline Population $(\mathrm{P}) \S$ & 1 & 5.494 & 2.722 & 0.208 & 0.065 & 2.554 & 0.82 \\
\hline Genotype (G)\| & 8 & 2.018 & $6.516^{* * *}$ & 3.226 & $5.339 * * *$ & 3.115 & $5.235 * * *$ \\
\hline $\mathrm{E} \times \mathrm{P} \pi$ & 3 & 1.233 & 1.727 & 1.764 & 1.544 & 0.481 & 0.501 \\
\hline $\mathrm{E} \times \mathrm{G} \|$ & 24 & 0.714 & $2.304 * *$ & 1.143 & $1.892 *$ & 0.96 & $1.613 \dagger$ \\
\hline Error & 80 & 0.31 & & 0.604 & & 0.595 & \\
\hline
\end{tabular}

Note: PCA was of six traits of transplanted corals. The genotype factor is nested within the population factor. Refer to Table 3 for component loadings.

$* P<0.05$; ** $P<0.01$; *** $P<0.001 ; \dagger P<0.075$.

$\ddagger$ MS tested over MS $\mathrm{E} \times \mathrm{P} ; \S$ MS tested over $\mathrm{MS}_{\mathrm{G}} ; \|$ MS tested over MS $\mathrm{S}_{\text {error }} ;$ I[ MS tested over $\mathrm{MS}_{\mathrm{E} \times \mathrm{G}}$.

types sampled within a population were separated by $>25 \mathrm{~m}$, strongly suggests that all 10 genotypes were genetically unique (Jeffreys et al. 1985b, Lewontin and Hartl 1991).

\section{Discussion}

The goals of this study were to determine whether the polymorphism demonstrated by Madracis mirabilis is due to phenotypic plasticity, and whether there is variation in reaction norms among genotypes and between populations of this species. The results demonstrate numerous morphological changes in response to transplantation to a new environment as well as significant genotype $\times$ environment interactions. The phenotypic changes of both populations resulted in the transplants becoming similar to resident conspecifics in each treatment environment. Analysis of the PCA results with ANOVA found a significant environmental

\section{A) DB10 Genotypes}
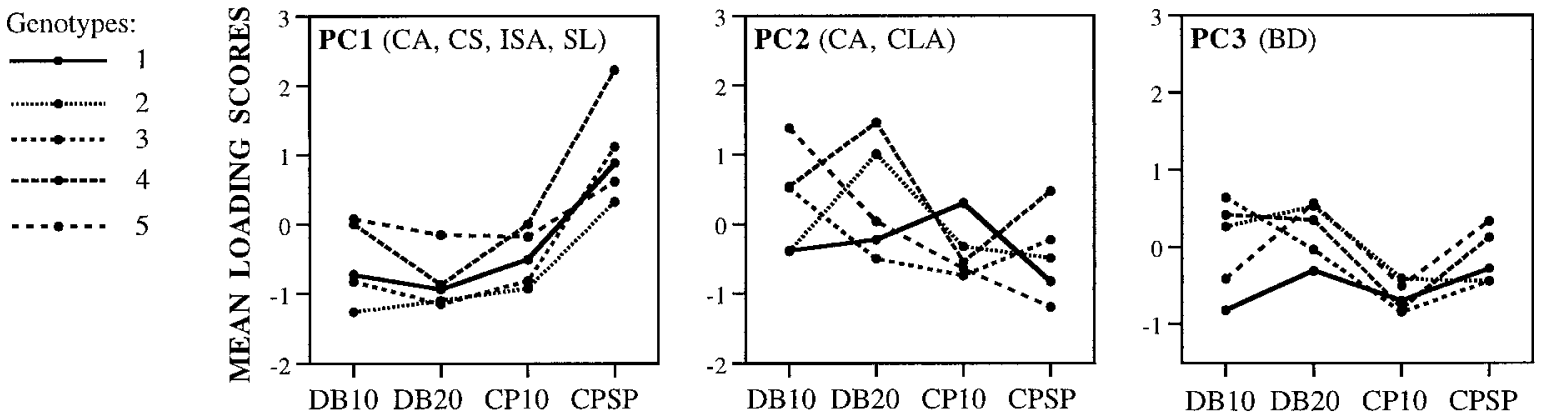

\section{B) CP10 Genotypes}
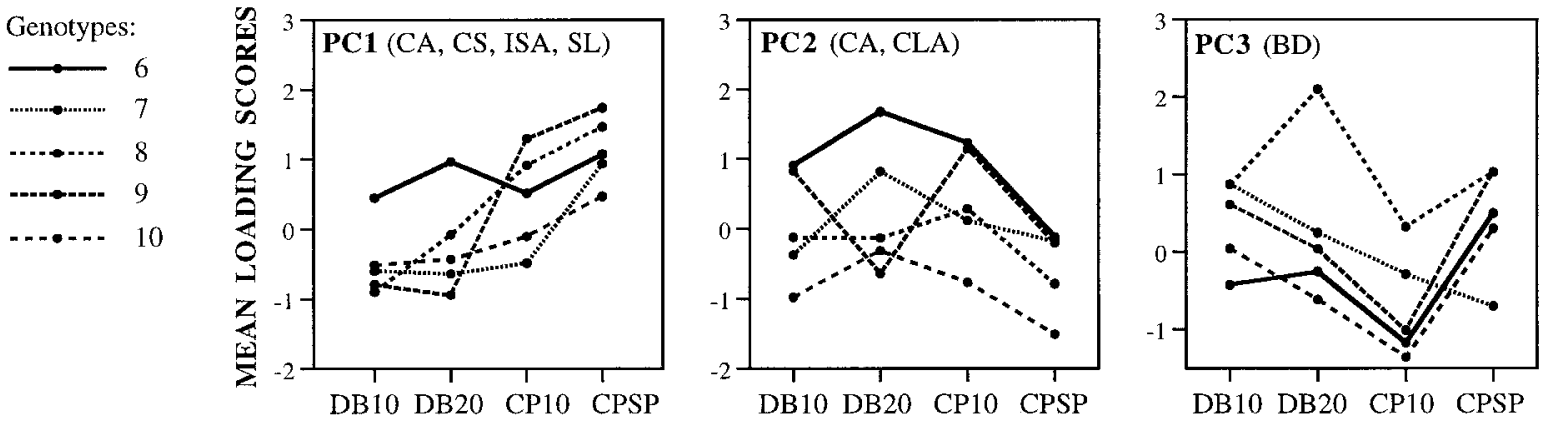

ENVIRONMENT

FIG. 4. Reaction norms of the first three principal components $(\mathrm{PC} 1-3)$ in response to the environmental treatments. The most heavily loaded traits for each PC are in parentheses. (A) Dairy Bull (DB10) genotypes; (B) Columbus Park (CP10) genotypes. Values are untransformed means. Refer to Table 1 for a summary of environmental characteristics of each treatment environment and to Fig. 2 for trait abbreviations. DB10, Dairy Bull at 10 m; DB20, Dairy Bull at 20 m; CP10, Columbus Park at $10 \mathrm{~m}$; CPSP, Columbus Park Springs at $10 \mathrm{~m}$. 

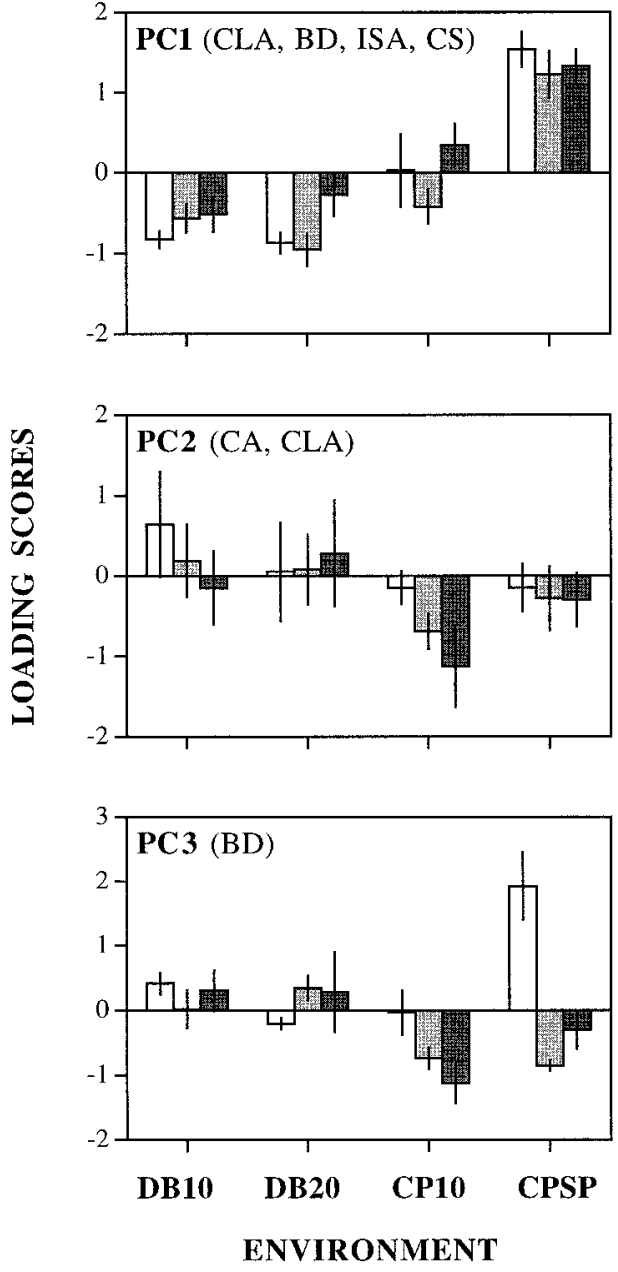

resident corals DB 10 corals

CP10 corals

FIG. 5. Mean scores $( \pm 1 \mathrm{SE})$ for the first three principal components (PC1-3) of transplanted and resident corals in the four treatment environments. The most heavily loaded traits for each PC are in parentheses. DB10, Dairy Bull at 10 m; DB20, Dairy Bull at $20 \mathrm{~m}$; CP10, Columbus Park at 10 $\mathrm{m}$; CPSP, Columbus Park Springs at $10 \mathrm{~m}$.
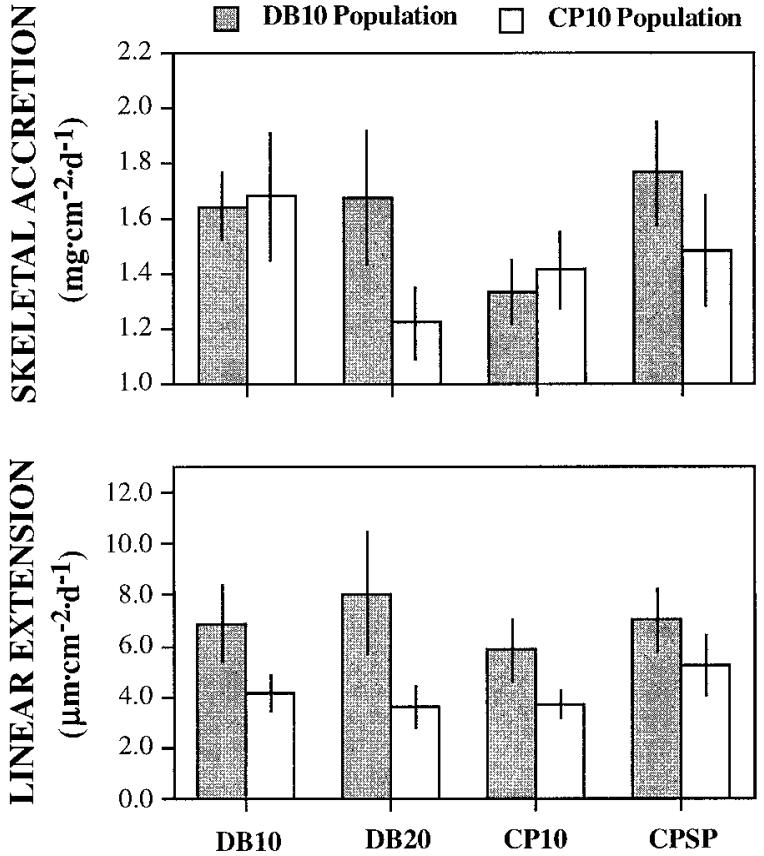

ENVIRONMENT

FIG. 6. Two measures of growth for the two transplanted populations in the four treatment environments. Values are untransformed means and standard errors. ANOVA found no significant variation among environments or between populations (Table 6). DB10, Dairy Bull at 10 m; DB20, Dairy Bull at $20 \mathrm{~m}$; CP10, Columbus Park at $10 \mathrm{~m}$; CPSP, Columbus Park Springs at $10 \mathrm{~m}$.

effect on PC1, which was defined primarily by corallite architectural traits including corallite spacing, columella area, intersepta area, and septa length, and on PC3, which was defined almost entirely by branch diameter (Tables 3 and 4). These five traits vary significantly among corals naturally living in the four treatment environments (Table 2). In contrast, the main environment effect was insignificant for PC2, which was defined mainly by corallite area, a trait that varies among corallites on a single branch and among genotypes, but not among environments (Table 2). While

Table 5. Results of ANOVA testing the effects of the treatment environment and "population" (transplanted or resident corals) on the first three principal components (PC1-3) from PCA of five skeletal characters of both resident and transplanted corals.

\begin{tabular}{|c|c|c|c|c|c|c|c|}
\hline \multirow[b]{2}{*}{ Source } & \multirow[b]{2}{*}{ df } & \multicolumn{2}{|c|}{ PC1 } & \multicolumn{2}{|c|}{ PC2 } & \multicolumn{2}{|c|}{ PC3 } \\
\hline & & MS & $F$ & MS & $F$ & MS & $F$ \\
\hline Environment (E) & 3 & 13.836 & $47.117 *$ & 0.798 & 0.754 & 2.740 & $\ldots$ \\
\hline Population $(\mathrm{P})$ & 2 & 0.825 & 2.811 & 0.477 & 0.450 & 4.139 & $\ldots$ \\
\hline $\mathrm{E} \times \mathrm{P}$ & 6 & 0.291 & 0.990 & 0.806 & 0.761 & 2.954 & $5.722 *$ \\
\hline Error & 48 & 0.294 & & 1.059 & & 0.516 & \\
\hline
\end{tabular}

Note: The purpose of this analysis was to compare the morphologies of the corals transplanted into each environment with the resident corals naturally living in those environments. Refer to Table 3 for component loadings. Significance tests of the two main effects were not performed for PC 3 due to the significance of the interaction term.

$* P<0.05$. 
TABLE 6. Results of three-way nested ANOVA testing the effects of the treatment environment, origin population, and genotype on linear extension and skeletal accretion. The genotype factor is nested within the population factor. All $F$ ratio tests were nonsignificant $(P>0.05)$.

\begin{tabular}{|c|c|c|c|c|c|}
\hline \multirow[b]{2}{*}{ Source } & \multirow[b]{2}{*}{$\mathrm{df}$} & \multicolumn{2}{|c|}{$\begin{array}{c}\text { Linear } \\
\text { extension }\end{array}$} & \multicolumn{2}{|c|}{$\begin{array}{c}\text { Skeletal } \\
\text { accretion }\end{array}$} \\
\hline & & MS & $F$ & MS & $F$ \\
\hline Environment $(\mathrm{E}) \dagger$ & 3 & 0.4880 & 6.5497 & 0.0674 & 1.1328 \\
\hline Population $(\mathrm{P}) \ddagger$ & 1 & 2.2280 & 2.3863 & 0.1296 & 0.7403 \\
\hline Genotype $(\mathrm{G}) \S$ & 8 & 0.9337 & 1.8155 & 0.1750 & 0.2811 \\
\hline $\mathrm{E} \times \mathrm{P} \|$ & 3 & 0.0745 & 0.1354 & 0.0595 & 0.6979 \\
\hline $\mathrm{E} \times \mathrm{G} \S$ & 24 & 0.5502 & 1.0697 & 0.0853 & 1.3702 \\
\hline Error & 80 & 0.5143 & & 0.0623 & \\
\hline
\end{tabular}

$\dagger$ MS tested over $\mathrm{MS}_{\mathrm{E} \times \mathrm{P}}$.

\$ MS tested over $\mathrm{MS}_{\mathrm{G}}$.

$\S$ MS tested over MS

$\|$ MS tested over $\mathrm{MS}_{\mathrm{E} \times \mathrm{G}}$.

this study did not attempt to determine which environmental factors caused the observed plastic changes, previous studies suggest that water velocity and irradiance are two particularly important factors in determining coral morphology (Dustan 1975, Graus and Macintyre 1982, Sebens and Done 1992). Both of these factors vary among the four treatment environments used in the present study.

Coral genotype also significantly affected all six measured traits, demonstrating that both the genotype and the environment act synergistically to determine morphology in Madracis mirabilis. This finding may explain field observations of substantial morphological variation between neighboring genotypes of $M$. mirabilis, which appeared to have been experiencing identical environmental conditions (J. F. Bruno, personal observations). As there was no population-level genetic effect and no population $\times$ environment interaction, the origin of each population had little effect on coral morphology. This apparent lack of genetic variation between the experimental populations is further supported by the similarity of their reaction norms (Fig. 3 ) and is most likely due to gene flow between them.

Significant genotype $\times$ environment interactions for PC1 (combined corallite traits) and PC2 (corallite area), and a marginally significant $\mathrm{G} \times \mathrm{E}$ for PC3 (branch diameter), indicate among-genotype variation in the directions and/or magnitudes of plastic responses. Such variation is most likely due to genetic differences among the genotypes. However, the significance of the genotype effect and the $\mathrm{G} \times \mathrm{E}$ effect may also have been influenced by residual effects of the origin environment. This $\mathrm{G} \times \mathrm{E}$ interaction is illustrated by the reaction norm of genotype 8 , which was qualitatively different than the other four CP genotypes for both intersepta area and branch diameter (Figs. 3 and 4). Intraspecific variation in plasticity among genotypes has also been reported in the corals Montastraea annularis and Siderastrea sideria (Foster 1979) and in numerous terrestrial plants and other organisms (Miller and Fowler 1993, Schmitt 1993).
TABLE 7. Banding patterns of DNA fingerprints from the animal DNA of eight aggregations of Madracis mirabilis.

\begin{tabular}{|c|c|c|c|c|c|c|c|c|c|}
\hline \multirow[b]{2}{*}{ Bin (bp) } & \multicolumn{8}{|c|}{ Genotype } & \multirow[b]{2}{*}{ Freq. } \\
\hline & 2 & 3 & 4 & 5 & 6 & 7 & 8 & 9 & \\
\hline $10000-8920$ & & & & & + & & & & 0.125 \\
\hline $8919-7956$ & & & & & & & & & 0.000 \\
\hline $7955-7096$ & & & & & & & & & 0.000 \\
\hline $7095-6329$ & + & + & & & & & & & 0.250 \\
\hline $6328-5645$ & & & & & & & & & 0.000 \\
\hline $5644-5035$ & + & & & & & & & + & 0.250 \\
\hline $5034-4491$ & + & + & + & & & + & & + & 0.625 \\
\hline $4490-4005$ & + & & & + & + & & + & & 0.500 \\
\hline $4004-3573$ & + & + & & & + & & + & + & 0.625 \\
\hline $3572-3186$ & + & + & + & + & & + & + & + & 0.875 \\
\hline $3185-2842$ & + & + & + & & + & + & & + & 0.750 \\
\hline $2841-2535$ & + & + & & + & & + & + & + & 0.750 \\
\hline $2534-2261$ & + & & & + & + & + & & + & 0.625 \\
\hline $2260-2017$ & + & + & + & & & & + & + & 0.625 \\
\hline 2016-1799 & + & + & + & & & + & + & & 0.625 \\
\hline 1798-1604 & + & + & + & & & + & & & 0.500 \\
\hline Bands: & 12 & 9 & 6 & 4 & 5 & 7 & 6 & 8 & \\
\hline
\end{tabular}

Note: Bands were allocated to 1 of 12 bins between 1.6 and $10 \mathrm{~kb}$ in size. The number of bands is shown for each genotype and band frequencies are shown for each bin. Genotypes 2-5 were from the Dairy Bull population (DB10) and genotypes 6-9 were from the Columbus Park population (CP10). $+=$ band present.

Although the exact mechanism is not well understood (Stearns 1989, Via 1993), plasticity itself is thought to be affected by natural selection (Bradshaw 1965). Thus, the detection of $\mathrm{G} \times \mathrm{E}$ as in the present study is important because such genetic variation for plasticity is necessary for natural selection to act on character reaction norms (Via and Lande 1985, Scheiner 1993, Via et al. 1995).

A comparison of the multivariate morphology of the transplanted and the resident corals indicated that many of the phenotypic changes resulted in the transplants becoming morphologically similar to resident conspecifics in each treatment environment. These findings together with the uniformity of reaction norms between the transplanted populations suggest that phenotypic plasticity in this species is not random, but instead is a predictable response to a single or a suite of environmental factors. The similarity of PC1 among the transplanted and resident corals is apparent in Fig. 5. This figure also suggests that the significant population $\times$ environment term for PC3 is mainly due to a difference between transplants and residents in branch diameter in the CPSP environment. Although this trait was plastic (Table 4, Figs. 3 and 4) and displayed an increase in 5 of the 10 genotypes transplanted to CPSP (Fig. 4), it had not changed enough during the 96-d transplant period to reach the diameter of the resident conspecifics.

A number of studies have investigated the functional significance of skeletal morphology in corals, including its effect on zooplanktivory (Helmuth and Sebens 1993), mass transfer (Patterson 1992), muscular attachment (Brown et al. 1983), sediment rejection (Hub- 
bard and Pocock 1972), and susceptibility to fragmentation (Highsmith 1982). While plasticity can be beneficial, neutral, and even detrimental (Bradshaw 1965), there is some experimental evidence that morphological plasticity in Madracis mirabilis could be ecologically advantageous (Bruno 1995). For example, in $M$. mirabilis branch spacing is inversely related to branch diameter (Tables 2 and 3) and to water velocity (Table 1; Bruno 1995, Sebens et al. 1997), as it is in other coral species (e.g., Lesser et al. 1994). Previous laboratory flume studies have demonstrated that branch spacing and flow can interact to affect both the feeding efficiency (Sebens et al. 1997) and respiration rate of M. mirabilis (Bruno 1995). In low-flow conditions, increased branch spacing results in higher respiration and particle capture rates (Bruno 1995, Sebens et al. 1997), while in high-flow conditions decreased branch spacing increases feeding efficiency (Sebens et al. 1997). Therefore, the phenotype appears to "match" local environmental conditions in a way that laboratory studies and biomechanical theory (e.g., Patterson 1992) predict would be beneficial. The results of the fitness estimates of the transplanted corals are concordant with these predictions: corals from both populations were able to maintain similar growth rates and experienced a relatively high survivorship in four very different environments (Table 6, Fig. 6). In other words, they displayed flat fitness reaction norms characteristic of generalist genotypes (Schlichting and Pigliucci 1995). Thus, phenotypic plasticity could facilitate the wide distribution of M. mirabilis (Schindler 1985) through the convergence of skeletal morphology to that of the local conspecifics. However, a more direct experimental approach would be necessary to determine unequivocally whether plasticity in M. mirabilis is beneficial. For example, short-term fitness estimates could be made on corals of various morphologies transplanted into different environments before and after the plastic changes induced by transplantation (e.g., Schmitt et al. 1995, Dudley and Schmitt 1996).

A better understanding of phenotypic plasticity might help resolve a number of long-standing problems in coral biology. One example is coral taxonomy, which has long been plagued by confusion arising from polymorphisms of the characteristics used to distinguish species (Ayre et al. 1991). Experimental taxonomy, where transplant experiments are used to determine the effect of the environment on coral morphology, could help to unambiguously distinguish closely related species. The large amount of morphological variation seen in Madracis mirabilis exemplifies this problem (Schindler 1985, Fenner 1993). The discrete separation of each morphotype could be mistaken as an indication that M. mirabilis is composed of a complex of sibling species (sensu Knowlton 1993), without the evidence of plasticity from this study which suggests otherwise. The use of reaction norms to examine how traits change in response to environmental factors provides a valu- able tool to better understand the functional morphology of polymorphic skeletal characteristics in corals and other clonal organisms. Investigations of plasticity may also aid in our understanding of how coral populations might respond to anthropogenic disturbances that are currently degrading many reefs (Grigg and Dollar 1990, Grigg 1993).

The results of this study demonstrate that a relatively long-lived, sessile organism employing both sexual and asexual reproduction can display substantial phenotypic plasticity and that reaction norms can vary significantly among clones. Such plasticity is likely to be an important component of the life history strategies of clonal populations, alleviating the negative effects of low genetic variation (Bradshaw 1965, Schlichting 1986). Morphological plasticity might also enable clonal species (and individual clones themselves) to occupy a broad range of habitats and allow those that are sessile to adapt to temporal changes in their environment. Therefore, investigations of phenotypic plasticity in predominantly asexual clonal taxa that have not previously received such attention could prove invaluable in providing insight into their evolution, speciation, population dynamics, and survival strategies in heterogeneous environments.

\section{ACKNOWLEDGMENTS}

We especially wish to thank Mark Bertness, Robert Carpenter, Nancy Emery, Ruth Gates, Sean Grace, Mary-Bestor Grant, Rick Grosberg, Sally Hacker, Shane Heschel, Amy Melendy, Johanna Schmitt, Dione Swanson, Jon Witman, and two anonymous reviewers for their comments, which greatly improved earlier drafts of this paper. Numerous dive buddies assisted us in the field in a variety of adverse conditions, including Marco Calavetta, Amy Melendy, Matt Mills, Sean Grace, Mark Warner, and many students of the East/West Marine Biology Program. We wish to thank the staff of the Discovery Bay Marine Laboratory (DBML) for their assistance. J. F. Bruno also thanks Sandy and Frank Bruno for their support. This research represents partial fulfillment for the Master of Science degree to J. F. Bruno at California State University, Northridge (CSUN) and was financially supported by a grant to P. J. Edmunds from the Office of Naval Research (number N00014-93-1-0440) and grants to J. F. Bruno from Sigma Xi, the CSUN office of Graduate Studies and International Programs, and the CSUN student projects committee (number 323430403). This is DBML contribution number 583.

\section{Literature Cited}

Ayre, D. J. 1984. The effects of sexual and asexual reproduction on geographic variation in the sea anemone Actinia tenebrosa. Oecologia 62:222-229.

Ayre, D. J., J. E. N. Veron, and S. L. Dufty. 1991. The corals Acropora palifera and Acropora cuneata are genetically and ecologically distinct. Coral Reefs 10:13-18.

Ayre, D. J., and B. L. Willis. 1988. Population structure in the coral Pavona cactus: clonal genotypes show little phenotypic plasticity. Marine Biology 99:495-505.

Bak, R. P. M., and S. R. Criens. 1981. Survival after fragmentation of colonies of Madracis mirabilis, Acropora palmata, and A. cervicornis (Scleractinia) and the subsequent impact of a coral disease. Proceedings of the Fourth International Coral Reef Symposium 2:221-227.

Bak, R. P. M., and M. S. Engel. 1979. Distribution abundance 
and survival of juvenile hermatypic corals (Scleractinia) and the importance of life history strategies in the parent coral community. Marine Biology 54:341-352.

Bradshaw, A. D. 1965. Evolutionary significance of phenotypic plasticity in plants. Advances in Genetics 13:115155.

Brakel, W. H. 1976. The ecology of coral shape: microhabitat variation in the colony form and corallite structure of Porites on a Jamaican reef. Dissertation. Yale University, New Haven, Connecticut, USA.

Brown, B. E., R. Hewit, and M. D. Le Tissier. 1983. The nature and construction of skeletal spines in Pocillopora damicornis (Linnaeus). Coral Reefs 2:81-89.

Brown, B. E., L. Sya'rani, and M. D. Le Tissier. 1985. Skeletal form and growth in Acropora aspera (Dana) from the Pulau Seribu, Indonesia. Journal of Experimental Marine Biology and Ecology 86:139-150.

Bruno, J. F. 1995. The adaptive value of phenotypic plasticity in the scleractinian coral Madracis mirabilis. Master's thesis. California State University, Northridge, California, USA.

Chornesky, E. A. 1983. Induced development of sweeper tentacles on the reef coral Agaricia agaricites: a response to direct competition. Biological Bulletin 165:569-581.

Connell, J. H. 1973. Population ecology of reef-building corals. Pages 205-245 in O. A. Jones and R. Endean, editors. Biology and geology of coral reefs. Volume 2. Academic Press, New York, New York, USA.

Davies, P. S. 1989. Short-term growth measurements of corals using an accurate buoyant weighing technique. Marine Biology 101:389-395.

Dudley, S. A., and J. Schmitt. 1996. Testing the adaptive plasticity hypothesis:density-dependent selection on manipulated stem length in Impatiens capensis. American Naturalist 147:445-465.

Dustan, P. 1975. Growth and form in the reef-building coral Montastrea annularis. Marine Biology 33:101-107.

D'Elia, C. F., K. L. Webb, and J. W. Porter. 1981. Nitraterich groundwater inputs to Discovery Bay, Jamaica: a significant source of $\mathrm{N}$ to local coral reefs? Bulletin of Marine Science 31:903-910.

Edmunds, P. J. 1989. An energy budget for Porites porites (Scleractinia), growing in a stressed environment. Coral Reefs 8:37-43.

Edmunds, P. J., and J. F. Bruno. 1996. The importance of scale in ecology: kilometer-wide variation in coral reef communities. Marine Ecology Progress Series 143:165171.

Fenner, D. P. 1993. Species distinctions among several Caribbean stony corals. Bulletin of Marine Science 53:10991116.

Forst, S., and M. Inouye. 1988. Environmentally regulated gene expression for membrane proteins in Escherichia coli. Annual Review of Cell Biology 4:21-42.

Foster, A. B. 1979. Phenotypic plasticity in the reef corals Montastraea annularis (Ellis and Solander) and Siderastrea siderea (Ellis and Solander). Journal of Experimental Marine Biology and Ecology 39:25-54.

- 1980. Environmental variation in skeletal morphology within the Caribbean reef corals Montastraea annularis and Siderastrea siderea. Bulletin of Marine Science 30: 678-709.

Fry, J. D. 1992. The mixed-model analysis of variance applied to quantitative genetics: biological meaning of the parameters. Evolution 46:540-550.

Gauch, H. G., Jr., 1982. Multivariate analysis in community ecology. Cambridge University Press, Cambridge, England.

Gibbs, H. L., P. T. Boag, B. N. White, P. J. Weatherhead, and L. M. Tabak. 1991. Detection of a hypervariable DNA locus in birds by hybridization with a mouse MHC probe. Molecular Biology and Evolution 8:433-446.

Gleason, D. F. 1992. The control and adaptive significance of morphological variation in the reef coral Porites astreoides. Dissertation. University of Houston, Houston, Texas, USA.

Goreau, T. F. 1959. The ecology of Jamaican coral reefs I. Species composition and zonation. Ecology 40:67-90.

Goreau T. F., and N. I. Goreau. 1973. The ecology of Jamaican coral reefs. II. Geomorphology, zonation, and sedimentary phases. Bulletin of Marine Science 23:399-464.

Graus, R. R., and I. G. Macintyre. 1982. Variation in growth forms of the reef coral Montastrea annularis (Ellis and Solander): a quantitative evaluation of growth response to light distribution using computer simulation. Smithsonian Contributions to Marine Science 12.

Grigg, R. W. 1993. Future prospects for coral reef science and species beyond the reef. Coral Reefs 12:55-56.

Grigg, R. W., and S. J. Dollar. 1990. Natural and anthropogenic disturbance on coral reefs. Pages 439-452 in Z. Dubinsky, editor. Ecosystems of the world 25: coral reefs. Elsevier, Amsterdam, The Netherlands.

Harvell, C. D. 1986. The ecology and evolution of inducible defenses in a marine bryozoan: cues, costs, and consequences. American Naturalist 128:810-823.

Helmuth, B., and K. Sebens. 1993. The influence of colony morphology and orientation to flow on particle capture by the scleractinian coral Agaricia agaricites (Linnaeus). Journal of Experimental Marine Biology and Ecology 165:251278.

Highsmith, R. C. 1982. Reproduction by fragmentation in corals. Marine Ecology Progress Series 7:207-226.

Hoegh-Guldberg, O. 1988. A method for determining the surface area of corals. Coral Reefs 7:113-116.

Hubbard, J. A. E. B., and Y. P. Pocock. 1972. Sediment rejection by recent scleractinian corals: a key to paleoenvironmental reconstruction. Geologische Rundschau 61: $598-626$

Hughes, R. N. 1983. Evolutionary ecology of colonial-reef organisms, with particular reference to corals. Biological Journal of the Linnean Society 20:39-58.

- 1989. A functional biology of clonal animals. Chapman and Hall, London, England.

Hughes, T. P., and J. H. Connell. 1987. Population dynamics based on size or age? A reef-coral analysis. American Naturalist 129:818-829.

Hughes, T. P., and J. B. C. Jackson. 1985. Population dynamics and life histories of foliaceous corals. Ecological Monographs 55:141-166.

Hunter, C. L. 1993. Genotypic variation and clonal structure in coral populations with different disturbance histories. Evolution 47:1213-1228.

Jackson, J. B. C. 1979. Morphological strategies of sessile animals. Pages 499-555 in G. Larwood and B. R. Rosen, editors. Biology and systematics of colonial organisms. Academic Press, New York, New York, USA.

Jackson, J. B. C., and A. G. Coates. 1986. Life cycles and evolution of clonal (modular) animals. Philosophical transactions of the Royal Society of London 313:7-222.

Jeffreys, A. J., V. Wilson, and S. L. Thein. 1985a. Individualspecific 'fingerprints' of human DNA. Nature 316:76-79.

Jeffreys, A. J., V. Wilson, and S. L. Thein. 1985b. Hypervariable 'minisatellite' regions in human DNA. Nature 314: $67-74$.

Jolliffe, I. T., 1986. Principal components analysis. SpringerVerlag, New York, New York, USA.

Knowlton, N. 1993. Sibling species in the sea. Annual Review of Ecology and Systematics 24:189-216.

Lang, J. C., and E. A. Chornesky. 1990. Competition between scleractinian reef corals - a review of mechanisms 
and effects. Pages 209-252 in Z. Dubinsky, editor. Ecosystems of the world 25: coral reefs. Elsevier, Amsterdam, The Netherlands.

Lesser, M. P., V. M. Weis, M. P. Patterson, and P. L. Jokiel. 1994. Effects of morphology and water motion on carbon delivery and productivity in the reef coral, Pocillopora damicornis (Linnaeus): diffusion barriers, inorganic carbon limitation, and biochemical plasticity. Journal of Experimental Marine Biology and Ecology 178:153-179.

Lewis, J. B., and P. V. R. Snelgrove. 1990. Corallum morphology and composition of crustacean cryptofauna of the hermatypic coral Madracis mirabilis. Marine Biology 106: 267-272.

Lewontin, R. C., and D. L. Hartl. 1991. Population genetics in forensic DNA typing. Science 254:1745-1750.

Liddell, W. D., and S. L. Olhorst. 1987. Patterns of reef community structure, North Jamaica. Bulletin of Marine Science 40:311-329.

Liddell, W. D., and S. L. Olhorst. 1992. Ten years of change on a Jamaican fringing reef. Proceedings of the Seventh International Coral Reef Symposium, Guam 1:144-150

Lively, C. M. 1986. Predator-induced shell dimorphism in the acorn barnacle Chathamalus anisopoma. Evolution 40: 232-242.

Maragos, J. E. 1972. A study of the ecology of Hawaiian reef corals. Dissertation. University of Hawaii, Honolulu, Hawaii, USA.

Martín-Mora, E., F. C. James, and A. W. Stoner. 1995. Developmental plasticity in the shell of the queen conch Strombus gigas. Ecology 76:981-994.

Meesters, E. H., and R. P. M. Bak. 1995. Age-related deterioration of a physiological function in the branching coral Acropora palmata. Marine Ecology Progress Series 121: 203-209

Meyer, A. 1987. Phenotypic plasticity and heterochrony in Cichlasoma managuense (Pisces, Cichlidae) and their implications for speciation in cichlid fishes. Evolution 41: $1357-1369$.

Miller, R. E., and N. L. Fowler. 1993. Variation in reaction norms among populations of the grass Bouteloua rigidiseta. Evolution 47:1446-1455.

Nichols, S., 1977. On the interpretation of principal components analysis in ecological contexts. Vegetatio 34:191197.

Palumbi, S. R. 1984. Tactics of acclimation: morphological changes of sponges in an unpredictable environment. Science 225: 1478-1480.

Patterson, M. R. 1992. A mass transfer explanation of metabolic scaling relations in some aquatic invertebrates and algae. Science 255:1421-1423.

Potts, D. C. 1984. Generation times and the Quaternary evolution of reef-building corals. Paleobiology 10:48-58.

Potts, D. C., T. J. Done, P. J. Isdale, and D. A. Fisk. 1985 Dominance of a coral community by the genus Porites (Scleractinia). Marine Ecology Progress Series 23:79-84.

Scheiner, S. M. 1993. Genetics and evolution of phenotypic plasticity. Annual Review of Ecology and Systematics 24 $35-68$.

Scheiner, S. M., and C. J. Goodnight. 1984. The comparison of phenotypic plasticity and genetic variation in populations of the grass Danthonia spicata. Evolution 38:845855.

Schindler, J. S. 1985. Environmental variation in the genus Madracis (Scleractinia) from the north coast of Jamaica Master's thesis. George Washington University, Washington, D.C., USA.

Schlichting, C. D. 1986. The evolution of phenotypic plasticity in plants. Annual Review of Ecology and Systematics 17:667-693.
Schlichting, C. D., and M. Pigliucci. 1995. Gene regulation, quantitative genetics and the evolution of reaction norms. Evolutionary Ecology 9:154-168.

Schmitt, J. 1993. Reaction norms of morphological and lifehistory traits to light availability in Impatiens capensis. Evolution 47:1654-1668.

Schmitt, J., A. C. McCormac, and H. Smith. 1995. A test of the adaptive plasticity hypothesis using transgenic and mutant plants disabled in phytochrome-mediated elongation responses to neighbors. American Naturalist 146:937-953.

Sebens, K. P. 1987. The ecology of indeterminate growth in animals. Annual Review of Ecology and Systematics 18: 371-407.

Sebens, K. P., and T. J. Done. 1992. Water flow, growth form and distribution of scleractinian corals: Davies Reef, (GBR), Australia. Proceedings of the Seventh International Coral Reef Symposium 1:557-568.

Sebens, K. P., J. Witting, and B. Helmuth. 1997. Effects of water flow and branch spacing on particle capture by the reef coral Madracis mirabilis (Duchassaing and Michelotti). Journal of Experimental Marine Biology and Ecology 211: $1-28$.

Stearns, S. C. 1989. The evolutionary significance of phenotypic plasticity. BioScience 39:436-445.

Stoddart, J. A. 1983. Asexual production of planulae in the coral Pocillopora damicornis. Marine Biology 76:279-284

Sultan, S. E. 1987. Evolutionary implications of phenotypic plasticity in plants. Evolutionary Biology 21:127-176.

Sultan, S. E., and F. A. Bazzaz. 1993. Phenotypic plasticity in Polygonum persicaria. I. Diversity and uniformity in genotypic norms of reaction to light. Evolution 47:10091031.

Trussell, G. C. 1996. Phenotypic plasticity in an intertidal snail: the role of a common crab predator. Evolution 50: 448-454.

Tunnicliffe, V. 1981. Breakage and propagation of the stony coral Acropora cervicornis. Proceedings of the National Academy of Sciences (USA) 78:2427-2431.

Vaughan, T. W. 1911. The Madreporaria and marine bottom deposits of southern Florida. Carnegie Institution of Washington, Yearbook Number 9(1910):147-152.

1917. Corals and the formation of coral reefs. Annual Report of the Smithsonian Institution 1917:189-238

Veron, J. E. N. 1981. The species concept in 'Scleractinia of eastern Australia'. Proceedings of the Fourth International Coral Reef Symposium 2:183-186.

Veron, J. E. N., and C. C. Wallace. 1984. Scleractinia of eastern Australia Part V. Family Acroporidae. Monograph Series of the Australian Institute of Marine Science 6:1422.

Via, S. 1993. Adaptive phenotypic plasticity: target or by-product of selection in a variable environment? American Naturalist 14:352-365.

Via, S., R. Gomulkiewicz, G. De Jong, S. M. Scheiner, C. D. Schlichting, and P. H. Van Tienderen. 1995. Adaptive phenotypic plasticity: consensus and controversy. Trends in Ecology and Evolution 10:212-217.

Via, S., and R. Lande. 1985. Genotype-environment interactions and the evolution of phenotypic plasticity. Evolution 39:505-522.

West-Eberhard, M. J. 1989. Phenotypic plasticity and the origins of diversity. Annual Review of Ecology and Systematics 20:249-78.

Willis, B. L. 1985. Phenotypic plasticity versus phenotypic stability in the reef corals Turbinaria mesenterina and $\mathrm{Pa}$ vona cactus. Proceedings of the Fifth International Coral Reef Symposium 6:107-112

Zar, J. H. 1996. Biostatistical analysis. Prentice Hall, Englewood Cliffs, New Jersey, USA. 